\title{
Ayak Ülserasyonları İçin Kronik Böbrek Hastalığı Bir Risk Faktörü müdür?
}

\section{Dr. Öğr. Üyesi Vacide AŞıK ÖZDEMIR' ${ }^{1}$, Prof. Dr. Nesrin NURAL ${ }^{2}$}

${ }^{1}$ Recep Tayyip Erdoğan Üniversitesi Sağlık Bilimleri Fakültesi, Hemşirelik Bölümü, İç Hastalıkları Hemşireliği AD, RiZEE

${ }^{2}$ Karadeniz Teknik Üniversitesi Sağlık Bilimleri Fakültesi, Hemşirelik Bölümü, İç Hastalıkları Hemşireliği AD, TRABZON

DOI: http://dx.doi.org/10.29228/tjdn.52794

\section{Derleme}

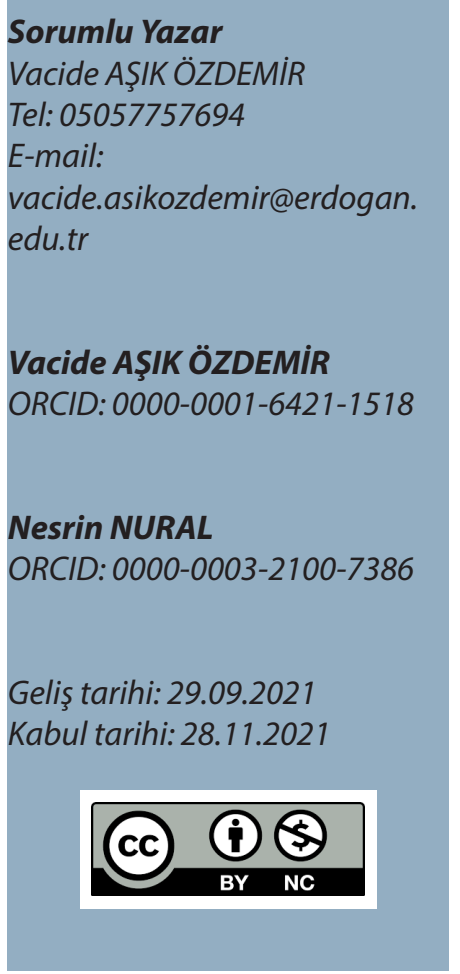

Özet

Ayakülserasyonlarının en iyi bilinen nedenlerinden biri diyabet olmasına rağmen, yapılan çaıısmalarda diyaliz, son dönem böbrek yetmezliği ve kronik böbrek hastalığının ayakta ülserasyon gelişmesinde ve seyrinde, hatta alt ekstremite amputasyonları için bağımsız risk faktörleri olduğu kanıtlanmıștır. Yapılan çalıșmalarda bu hasta gruplarında ayak ülserasyonları fiziksel-psikolojik sağlık, hareketlilik düzeyi, görme problemleri, beslenme durumu, sigara içme, hipoalbüminemi, düşük serum fosfor düzeyi, üremi, doku oksijenasyonu, üremik nöropati, periferik arter hastalığı, diyabet, anemi, alt ekstremitede ödem, enfeksiyonlara yatkınlık, diyaliz süresince ayak/bacakların bası altında kalması gibi nedenlerin yanısıra haftada iki ya da üç kez diyaliz tedavisi alma ile ilişkilendirilmektedir. Sonuç olarak diyabeti olan kişilerin ayak ülserasyonları açısından yüksek riskli kabul edildiği gibi, kronik böbrek yetmezliği olan yetişkinlerin de ayak ülserasyonu açısından büyük risk altında olduğu, diyabetli bireylere yapılan ayağa ilişkin değerlendirme ile eğitim ve bakım hizmetlerinin diyaliz tedavisi alan gruba da aynı önem ile verilmesinin gerekliliği ortadadır. Diyaliz hastaları genellikle diyaliz ortamının dışında bakımla temasını kaybederken, rutin diyaliz bakımının bir parçası olarak hemşireler tarafından değerlendirme, eğitim verme gibi koruyucu stratejiler ülserasyon ve amputasyon oranlarını azaltmak için anahtar olabilir. Bu derlemenin amacı ayak ülserasyonu gelişiminde kronik böbrek hastalığı ile ilişkili risk faktörlerini tanımlamaktır.

Anahtar Sözcükler: Ayak Ülserasyonu; Diyabet; Hemodiyaliz; Kronik Böbrek Hastalığı; Risk Faktörleri

\section{Abstract}

Although diabetes is one of the best-known causes of foot ulcerations, studies have proven that dialysis, end-stage renal disease and chronic kidney disease are independent risk factors for the development and course of foot ulceration, and even for lower extremity amputations. In the studies conducted, foot ulcerations in these patient groups were associated with receiving dialysis treatment 2 or 3 times a week as well as with the reasons such as physical-psychological health, mobility level, vision problems, nutritional status, smoking, hypoalbuminemia, low serum phosphorus level, uremia, tissue oxygenation, uremic neuropathy, peripheral arterial disease, diabetes, anemia, edema in the lower extremities, susceptibility to infections, pressure on the feet/ legs during dialysis. As a result, it is obvious that people with diabetes are considered to be at high risk for foot ulcerations, adults with chronic renal failure are also at great risk for foot ulceration, the evaluation of the foot and the education and care services for individuals with diabetes should be given to the group receiving dialysis treatment with the same importance. While dialysis patients often lose touch with care outside of the dialysis setting, preventive strategies such as assessment and training by nurses as part of routine dialysis care may be the key to reducing ulceration and amputation rates. The purpose of this review is to describe the risk factors associated with renal failure in the development of foot ulceration.

Keywords: Foot Ulceration; Diabetes; Hemodialysis; Chronic Kidney Disease; Risk Factors 


\section{Giriş}

Ayak ülserasyonları önemli mortalite ve morbiditeye neden olan dünya çapında bir halk sağlığı sorunudur (Saluja vd., 2020). Yara iyileşmesi hemostaz, inflamasyon, epitelizasyon ve skar oluşumunu izleyen bir dizi kompleks süreçten oluşur (Han ve Ceilley, 2017). Kronik ülserlerde komorbid hastalık varlığı bu süreçte aksamalara yol açar, yara sıklıkla enfekte olur, hareketliliği sınırlar ve amputasyon ile sonuçlanabilir (Beyene, Derryberry ve Barbul, 2020). Ayak ülserasyonlarının en iyi bilinen nedenlerinden biri diyabet ve periferik arter hastalığıdır (Reardon vd., 2020). Ancak yapılan çalışmalar kronik böbrek hastalığı $(\mathrm{KBH})$, son dönem böbrek yetmezliği (SDBY) ve hemodiyaliz (HD) tedavisinin de diyabetik ayak ülserlerinin gelişmesinde ve seyrinde risk faktörü olarak yer aldığını ortaya koymuştur (Valabhji, 2012; Kaminski vd., 2015; Kaminski vd., 2017). Diyabet ve SDBY birlikteliğinde ayak komplikasyonları ve alt ekstremite amputasyonlarının genel diyabet populasyonundan daha fazla olduğu, SDBY'nin enfeksiyon, ülser, gangren veya amputasyon olarak tanımlanan diyabetik ayak komplikasyonları ile ilişkili olduğu gösterilmiş ve SDBY diyabetik ayak risk spektrumu arasında yeni bir risk faktörü olarak tanımlanmıştır (Ndip, Lavery ve Boulton, 2010). Hemodiyaliz tedavisi alan diyabetik hastalarda, diyaliz tedavisinin ayak ülserasyonları ve alt ekstremite amputasyonları için bağımsız ve güçlü bir risk faktörü olduğu bildirilmiştir (Ndip vd., 2010). Aynı zamanda diyaliz hastalarında alt ekstremite amputasyonlarının yüksek prevalansa $(\% 13,3)$ sahip olduğu, kronik ayak ülserlerinin tekrarlı hastane yatışlarının da önemli nedenlerinden biri olduğu tespit edilmiştir (Lavery vd., 2015; Gilhotra vd., 2016). Günümüzde diyabetten bağımsız olarak HD tedavisi alan hastalarda da, ilişkili faktörler henüz tam olarak anlaşılamasa da ayak ülserasyonu prevalansının yüksek olduğunu gösteren uluslararası çalışmalar mevcuttur (Al-Thani vd., 2014; Brekelmans vd., 2019). Bu veriler ayak ülserasyonlarının gelişmesi ve seyrinde renal yetmezliğin etkisini göstermektedir. Diyabeti olan kişilerin ayak ülserasyonları açısından yüksek riskli kabul edildiği gibi, renal yetmezliği olan hastaların da ayak ülserasyonu açısından büyük risk altında olduğu, diyabeti olan hastalara yapılan ayağa ilişkin değerlendirme ile eğitim ve bakım hizmetlerinin renal yetmezliği olan hastalara da aynı önem ile ve yerinde ayak bakımı sağlayan diyaliz merkezlerinde hemşire tarafından verilmesinin gerekliliği yapılan uluslararası literatürde ortaya konmuştur (Brand, Musgrove, Jeffcoate ve Lincoln, 2016). Ayak değerlendirmesi ve bakımı ile ilgili eğitim verme hemşirelerin primer sorumlulukları arasındadır. Bu nedenle $\mathrm{KBH}$ olan hastaların hemşireler tarafından düzenli ayak değerlendirmesi ve öz-bakımına ilişkin eğitim faaliyetleri bu grupta ayak sağlığının korunmasında önemlidir (Wilson ve Lawrence, 2013; Allison ve Flanagin, 2020). Bu amaçla bu makalede ayak ülserasyonu gelişiminde renal yetmezlik ile ilişkili risk faktörleri derlenmiştir.

\section{Kronik Böbrek Hastalığı ve Ayak Ülserasyonları}

Renal yetmezliğin uzun zamandır yara iyileşmesini etkilediği bilinmekle birlikte renal yetmezliğin derecesine bağlı yara iyileşmesinin çeşitliliğindeki farlılıklara ilişkin bilinenler sınırlıdır (Maroz ve Simman, 2014; Scholnick, 2016). Kronik böbrek hastalığı, son dönem böbrek yetmezliği ve hemodiyaliz tedavisi ile ayak ülserasyonları arasındaki ilişki multifaktöriyeldir (Lewis, Raj ve Guzman, 2012; Maroz ve Simman, 2014). Literatürde ayak ülserasyonlarının gelişmesi görme problemleri, beslenme durumu, sigara içme, hipoalbüminemi, düşük serum fosfor düzeyi, üremi, doku oksijenasyonu, üremik nöropati, periferik arter hastalığı, diyabet, anemi, alt ekstremitede ödem, enfeksiyonlara yatkınlık, psikososyal sorunlar gibi nedenlerin yanısıra diyaliz süresince ayak/bacakların bası altında kalması gibi pek çok durum ile ilişkilendirilmektedir (Lewis, Raj ve Guzman, 2012). Diyabetik ayak patogenezinde yer alan üçlü triyad (periferik arter hastalığı, periferal nöropati ve enfeksiyon) dışında SDBY'ne özgü patogenetik özellikler periferik arter hastalığı (PAH) sıklığında artma, tıbbi önceliklerde değişme (HD tedavisi nedeniyle), azalmış doku oksijenasyonu (yaşanan hemodinamik değişiklikler, sistemik hipoksi, anemi ve ödem nedeniyle), artmış travma riski (kardiyovasküler otonomik nöropati ve post-diyaliz volüm değişikliklerinin neden olduğu postural hipotansiyon nedeniyle), artmış enfeksiyon riski (üremik toksinler ve/veya kötü beslenme nedeniyle) olarak özetlenebilir (Pappanas, Liakopoulos, Maltezos ve Stefanidis, 2007).

Kronik Böbrek Hastalığı Olan Hastalarda Ayak Ülserasyonu Gelişimini Etkileyen Faktörler

\section{Diabetes Mellitus}

Diyabet, ayak ülserasyonları gelişiminde iyi bilinen bir faktördür. Diyabetle birlikte böbrek hastalığı olanlarda, amputasyon da dahil olmak üzere, daha yüksek diyabetik ayak hastalığı insidansı vardır ve sonuçlar genellikle daha olumsuzdur. Bu hastalarda yüksek insidansa katkıda bulunan spesifik risk faktörleri olmakla birlikte böbrek hastalığının tüm kategorilerinde insidansın arttığı gösterilmiştir (Ndip vd., 2010). Diyabetik ayak ülseri ciddiyeti arttıkça GFH (Glomerül Filtrasyon Hızı)'ın azaldığı, dolayısıyla renal yetmezliğin derecesi ile diyabetik ayak ülserleri arasındaki güçlü ilişki gösterilmiştir (El Sharaawy, Ezzat, Mohab ve Elwasly, 2017).

\section{Üremi}

Normal koşullar altında sağlıklı böbrekler tarafından filtrelenen birçok bileşiğin retansiyonu, üremik sendromun gelişmesine yol açar. Üremik süreçte normal fizyolojik süreçler için hayati önem taşıyan bu retansiyon solütleri, böbrek fonksiyon bozukluğu nedeniyle fazla birikerek toksik hale gelmekte ve üremik toksinler olarak adlandırılmaktadır (Vanholder, Pletinck, Schepers ve Glorieux, 2018). Üremik toksinlerin yara iyileşmesini pek çok yolla etkilediği, hatta üreminin amputasyon olasılığı için en önemlifaktörlerarasındaolduğugösterilmiştir(Khanhvd.,2017).

Margolis ve ark.'nın 90.617 hasta ile yaptıkları gözlemsel çalışmada PAH'ın varlığı ile ilişkili olmayan alt ekstremite amputasyonu ve ayak ülserasyonu ile $\mathrm{KBH}^{\prime} ı$ n evresi arasında güçlü bir ilişki olduğu ortaya konmuştur. Hatta orta derecede $\mathrm{KBH}$ olan bireylerin bile alt ekstremite amputasyonu ve ayak ülserasyonu riski ile karşı karşıya oldukları belirtilmiştir (Margolis, Hofstad ve Feldman, 2008).

\section{Hemodiyaliz}

Diyaliz tedavisinin nöropati, periferik vasküler hastalık, ayak öz bakım önlemleri ve etnik köken gibi potansiyel değişkenlerden bağımsız olarak diyabette ayak ülseri oluşumu ile ilişkili olduğu, kılavuzlar ve rehberlerde yoğun ayak bakımı gerektiren ayak ülseri için önemli bir risk faktörü olarak diyalizin vurgulanmasının gerekliliği ortaya konmuştur (Ndip vd., 2010).

Hemodiyalizin kendisinin mikrovasküler kan akışında bir düşüşe neden olduğu gösterilmiştir. Kay ve ark.'nın yaptığı çalışmada diyabeti olan hasta grubunda, diyabeti olmayan gruba kıyasla HD esnasında ve sonrasında ayak parmağı kan basıncında önemli bir azalma olduğu saptanmıştır. Bu durumun, diyaliz sırasında ortaya çıkan hemodinamik değişikliklerin ve distal nöropatiye bağlı anormal vazomotor regülasyonun sonucu 
olabileceği düşünülmektedir (Kay vd., 2011; Foster vd., 2017).

Haftada üç kez diyaliz koltuğuna oturma nedeniyle topuklarda ve ayak parmaklarında oluşan basınç; ülser gelişimine ve ayak bakımı gibi kişisel bakım uygulamalarınında ihmale neden olabilir (Valabhji, 2012).

\section{Protein-Enerji Tükenmesi}

Optimum beslenme yara iyileşmesinin tüm aşamalarını sürdürmede önemli bir faktör olarak iyi bilinmektedir. Önemli herhangi bir yara hipermetabolik ve katabolik duruma yol açmakta ve beslenme ihtiyaçlarını büyük ölçüde arttırmaktadır. Yara iyileşmesi yeterli besin alımıyla ilişkilidir (Demling, 2009).

Diyaliz tedavisi (HD ya da PD) hastalarda önemli protein kaybına yol açar. Kronik böbrek hastalığı olan hastalarda özellikle SDBY veya Evre 5 olanlarda protein ve/veya enerji depoları giderek tükenir. $\mathrm{KBH}$ evre 4-5 olan hastaların \%5075 'inde görülen protein-enerji tükenmesi, artmış morbidite ve mortalite riski, inflamasyon ve azalmış yaşam kalitesi ile ilişkilidir (Meuwese, Carrero ve Stenvinkel, 2011; Ikizler vd., 2013).

Böbrek hastalarında protein-enerji tükenmesinin nedenleri arasında azalmış protein ve enerji alımı (anoreksia, uygun olmayan diyet kısıtlamaları, gastrointestinal hastalıklar, depresyon, yemek hazırlama zorlukları ve sosyo-ekonomik zorluklara bağlı), hiperkatabolizma, metabolik asidoz, azalmış fiziksel aktivite, azalmış anabolizma, sedanter yaşam stili, komorbiditeler ve diyaliz tedavisi (diyaliz tedavisi ile ilişkili aminoasit ve protein kaybı, inflamatuar süreçler, hipermetabolizma, rezidüel renal fonksiyon kaybı) sayılabilir (Sabatino vd., 2017).

\section{Periferal Arter Hastalığı}

Periferik arter hastalığının, böbrek hastalığı olanlarda özellikle de hemodiyaliz tedavisi alan hastalarda oldukça yaygındır. HD tedavisi alan hasta grubunda PAH prevalansının $\% 38,5$ olduğu, PAH'ın erken tespit edilmesinin, HD hastaları arasında daha da yüksek bir risk popülasyonunun belirlenmesinde değerli olduğu ortaya konmuştur (Al Thani vd., 2013). Kronik inflamasyon, malnütrisyon, sIVı retansiyonu, renin-anjiyotensin sisteminde değiş̧iklikler, hiperhomosisteinemi, anormal mineral metabolizması, dislipidemi, lipoprotein imbalansı ve oksidatif stres gibi KBH'a özgü risk faktörleri yanı sıra periferal vasküler hastalık için geleneksel risk faktörlerinin de varlığı nedeniyle $\mathrm{KBH}$ olan hastalar aterosklerotik plak formasyonu oluşumuna son derece yatkındır (De Vinuesa vd., 2005).

Diyaliz hastaları arasında vasküler kalsifikasyon çok yaygındır ve büyük olasılıkla PAH gelişimine majör katkıda bulunur. SDBY olan hastaların çoğu haftada yaklaşık dört saat boyunca üç seans HD tedavisi alırlar; bu da fosforun zayıf temizlenmesine, yüksek kalsiyum-fosfor ürünlerine ve artmış vasküler kalsifikasyona neden olur. Kalsiyum-fosfat ürünü ne kadar fazla olursa vasküler kalsifikasyonun derecesi ve mortalitesi de o oranda yüksek olur. SDBY ayrıca vasküler kalsifikasyonla ilişkili olan yüksek parathormon seviyesi ile de ilişkilidir (Lin vd., 2015; Cozzolino vd., 2019).

\section{Periferal Nöropati/Üremik Nöropati}

Diyaliz hastaları sağlıklı bireyler ile karşılaştırıldığında daha zayıf, daha az aktiftir ve egzersiz kapasitelerinde azalma vardır. Bu süreçler sıklıkla ağıı, yorgunluk ve zayıflığa yol açan SDBH'ın iyi bilinen nörolojik komplikasyonu olan üremik nöropati ile ilişkilidir (Krishnan, Pussell ve Kiernan, 2009).

Diyabetik nefropatiye neden olan aynı mikrovasküler hastalık süreci, diyabetik ayak hastalığının başlıca etiyolojik faktörü olan periferal nöropatiye de neden olmaktadır.
Diyabetik nefropatiye bağlı SDBY olan olguların hemen hemen tümünde periferik nöropatinin boyutu nefropatinin boyutunu yansıtır. Diyabeti olan hastalarda SDBY diyabetik nefropatiden kaynaklanmasa bile, diyabete sekonder olmayan periferik nöropati, üremiden ve vaskülitler gibi SDBY'nin başka nedenlerinden kaynaklanabileceği için sıklıkla mevcuttur. Bu nedenle diyabet ve SDBY olan hemen hemen tüm hastalarda periferik nöropati vardır (Ndip vd., 2010).

Periferik vasküler hastalığın da değişen katkısı olmakla birlikte nöropati, diyabette ayak ülserinin temel nedenidir. Diyabet ve eşzamanlı böbrek hastalığı olanlarda periferik vasküler hastalıkların daha fazla etkili olacağı düşünülmektedir (Valabhji vd., 2012). Koruyucu duyu kaybı, ayak parmakları ve topuklar, metatarsal başların plantar yönlerine olan basınç artışına rağmen hastalar tarafından bunun genellikle fark edilmemesine yol açar. Ağrı hissetmeme ya da ağrısızlık nedeniyle basınca neden olan durumun sürdürülmesi normal yara iyileşme sürecini engeller, böylece lezyonlar büyür, kronikleşir ve enfeksiyon gelişir. Yüzeysel enfeksiyonlar derinleşir, osteomiyelit genellikle ilk ülser oluşumunda görülür. Otonom nöropati arterio-venöz şantla sonuçlanır, böylece kapiller yataklarda perfüzyonu azaltır ve iyileşmeyi daha da tehlikeye atan mikrovasküler yetmezliğe neden olur. Otonom nöropati aynı zamanda terlemenin kaybına ve dolayısıyla cildin kuruyarak çatlamasına yol açar. Bu da cildin ilk bozulmasına neden olan başka bir faktördür (Valabhji vd., 2012).

\section{Enfeksiyona Yatkınlık/İmmünsupresyon}

Diyabetin enfeksiyon riskini arttırdığı iyi bilinmektedir. Bununla birlikte üreminin kendisi, vücudun enfeksiyonlara karşı savunma yeteneğini azaltan önemli immün sistem fonksiyon bozukluklarına neden olur. Kanıtlar, üreminin özellikle bakteriyel enfeksiyonlara karşı savunmada ana hücreler olan polimorfonükleer hücrelerin işlevini bozan doğal ve adaptif immün yanıtların bozulmasına neden olduğunu göstermektedir (Kato vd., 2008). Şiddetli böbrek hastalığındaki üremi, yara iyileşmesine karşı inflamatuar cevabı değiştirir ve bağışıklık sisteminin birçok yönünü tehlikeye sokarak bu hastaları enfeksiyona karşı daha duyarlı hale getirir. Hiporeaktif monositlere, nötrofillerin bakterisidal etkisinin baskılanmasına, T ve $B$ lenfosit fonksiyonunda azalmaya, doğal öldürücü hücre aktivitesinde bir azalmaya ve bakteriyel enfeksiyonlarla savaşan polimorfonükleer hücrelerin fonksiyonunun bozulmasına neden olur (Kato vd., 2008). İlk görülen ayak ülserlerinin büyük bir kısmı enfekte olur ve daha büyük bir oran osteomiyelit gibi daha derin yerleşimli enfeksiyonlara ilerler (Valabhji, 2012).

\section{Anemi}

Kronikböbrekhastalığıolanhastalardagenelliklekronikhastalıktankaynaklanananemivardır.Anemi,kırmızıkanhücrelerinin ömrünün kısalmasına ek olarak böbrek tarafından eritropoetin üretiminin azalmasından kaynaklanır (Maroz ve Simman, 2014).

Anemi, kötü doku oksijenlenmesi ve bozulmuş yara iyileşmesi ile ilişkilidir. Doku kanlanmasının zayıf olması, iyileşmenin önündeki ana engellerden birisidir. (Valabhji, 2012). Oksijenin varlığı prolin ve lizinin hidroksilasyonu, pro-kollajen lifler arasında çapraz bağların kurulması, kollajenin taşınması, fibroblast ve epitelyum hücrelerinin çoğalması, lökositlerin etkili bir şekilde işlev yapabilmesi, anjiogenez ve diğer süreçler için zorunludur. Yara kenarlarındaki göreceli hipoksi, fibroblastik cevabı arttırmakta, tamir için gerekli olan diğer hücresel elemanların da yara alanına göçüne yardım etmektedir. Bunun la beraber dokuda çok düşük olan oksijen seviyesi, enfekte 
edici bakteriler tarafından üretilen laktik asidin dokudaki pH'ı düşürmesi ile birlikte yara iyileşmesinin bozulmasına katkıda bulunmaktadır (Rodriguez, Felix, Woodley ve Shim 2008).

\section{Cilt Bozuklukları}

Ayak ülseri gelişmesi riskini arttıran, renal yetmezliği olan hastalara özgü cilt bozuklukları kalsiflaksis, nefrojenik sistemik fibrozis ve üremik kaşıntıdır.

\section{Kalsiflaksis}

Kalsiflaksis ya da kalsifik üremik arteriolopati genellikle SDBY olan hastalarda sonrasında iyileşmeyen nekrotik cilt ülserlerine bazen de gangrene yol açan, acı veren cilt lezyonlarıyla kendini gösteren bir komplikasyondur. Bu bozukluk, HD hastalarında \%4 oranında yaygınlıkla seyrek görülen ancak iyi tanımlanmış bir komplikasyondur. Kalsiflaksisin tam patofizyolojisi belirsizliğini korumakla birlikte, anormal kemik ve mineral metabolizması, hiperparotiroidizm ve vitamin $D$ tedavisinin bu bozukluğun gelişimine katkıda bulunduğu düşünülmektedir. Kalsiflaksis, RRT almayan KBH olanlarda da tarif edilmiştir ( $\mathrm{Ni}$ gwekar, Wolf, Sterns ve Hix, 2008).

Kalsiflaksis cilt nekrozuna ve son derece ağrılı, iyileşmeyen yaralara yol açar. Klinik prezantasyon akral bölgelerin daha az yaygın tutulumu ile birlikte sıklıkla kalça, uyluk ve karın üzerinde proksimal lezyonların (genellikle simetrik) gelişmesiyle karakterizedir. İyileşmeyen yaralar çoklu mikroorganizmalar, sepsis ve enfeksiyon için bir fırsat sağlar (Reslerova ve Moe, 2003).

Yapılan bir çalışma kalsiyum birikiminin prediyalizde başladığını, ancak vasküler düz kas hücresi savunma mekanizmalarını devre dışı bırakmada ve klinik olarak saptanabilir vasküler hasara yol açarak aşırı kalsifikasyonun gelişmesinde anahtar olay olan diyalizde, bu hücrelerde apoptosisin uyarılması ya da osteoblast benzeri hücrelere dönüşme süreci olduğunu göstermektedir (Shroff vd., 2008).

\section{Nefrojenik Sistemik Fibrozis (NSF)}

Nefrojenik fibroz dermopati olarak bilinen nefrojenik sistemik fibrozis (NSF) deride endurasyon, kalınlaşma ve sertleşme ile karakterize, tercihen ekstremiteleri etkileyen bir hastalıktır. Kalınlaşmış cilt, pruritusla birlikte epidermiste kırılmalara yol açarak hastaları ülserasyona ve üst üste binen enfeksiyonlara yatkın hale getirir. Histolojik olarak enflamasyon bulgularının yokluğu ayrıca fibroblastların ve elastik liflerin proliferasyonu, müsin birikimi ve yarıkların çevrelediği kalınlaşmış kollajen demetler ile karakterizedir. NSF, RRT almayan ileri renal yetmezliği olan hastalarda gözlemlenmiştir (Lewis vd., 2012).

\section{Üremik Pruritus}

Son dönem böbrek yetmezliğine bağlı kaşınma semptomunu tanımlayan bir terimdir. Böbrek yetmezliği hastaları muhtemelen mikrodolaşım ve onun ter bezi atrofisi üzerindeki olumsuz etkilerinden dolayı cilt kuruluğuna (kserozis) karşı duyarlı hale gelir. Tekrarlayan üremik kaşıntı kolay bir şekilde mekanik cilt travması, likenifikasyon (cildin kalınlaşması ve sertleşmesi), prurigo nodülaris (şiddetli kaşıntılı papül ve nodüllerle karakterize kronik bir deri hastalığı) ve perforan dermatozise yol açabilir (Maroz ve Simman, 2014).

Üremik pruritus, KBH ile ilişkili sık görülen bir deri hastalığıdır. Bu sendromun patofizyolojsi karmaşıktır ve iyi anlaşılamamıştır. Üremik pruritus, ciltte kırılmalara yol açıp, enfeksiyon etkenlerine giriş odağı oluşturarak ciltte ülserasyona yol açan basamakları başlatabilir (Lewis vd., 2012).

\section{Diğer Risk Faktörleri}

Son dönem böbrek yetmezliğindeki ayak ülserasyonu için bir başka önemli risk faktörü, hastaların kendi kişisel ayak bakımlarını ihmal etmeleridir. Diyaliz hastaları haftada üç gün diyalize bağlıdır ve özellikle ayak bakımı başta olmak üzere bakımlarının diğer yönlerini gözden kaçırma eğilimindedirler (Scholnick, 2016). Yapılan bir çalışmada diyaliz tedavisi gören hastaların çıplak ayakla yürüyüş gibi ayağa zarar veren davranışlarda bulunma eğiliminde oldukları, ayaklarını düzenli olarak kontrol etme ve ayak bakımı kliniklerine gitme oranlarının daha az olduğu sonucuna ulaşılmıştır. (Lincoln, Radford, Game ve Jeffcoate, 2008). Görme keskinliğinde azalma, yetersiz esneklik ve el becerisi hastanın ayakları üzerinde kendi kendine bakımını denetleme ve gerçekleştirme yeteneğini bozar. Diyaliz hastaları ile yapılan bir çalışmada hastaların sadece \%75'i yeterli görmeye, $\% 60$ ' yeterli beceriye ve \%55'i öz bakım için yeterli esnekliğe sahip olup, hastaların \%73,3'ünün öz bakımında desteğe ihtiyacı olduğu belirlenmiştir (Locking-Cusolito vd., 2005).

Diyaliz hastalarında depresyon en yaygın psikopatoloji olarak kabul edilmiş, HD hastaları için diğer kliniklerde uyum ve katılımı etkilediği gösterilmiştir. Depresyon uyumu etkileyecek ve hastanın bir podiatrist kliniğine ziyaretlerini devamlı hale getirme yeteneğini etkileyecek bir faktördür (Afsar ve Akman, 2009).

Çinko, yara iyileşme sürecinde hayati öneme sahip bir element olup otodebritman, keratinosit migrasyonunda artışa yol açıp, bakteriyel toksinlere karşı apoptosise direnç kazandırarak yara iyileşme sürecinde görev alır (Lewis vd., 2012). HD hastalarının \%40-78'inde çinko eksikliği olduğu ve çinkonun diyaliz ile atılabildiği birldirilmektedir (Kalantar-Zadeh ve Kopple, 2003).

Son dönem böbrek yetmezliği olan hastalarda eritropoezi optimize etmek için yaygın olarak kullanılan demir replasmanı, bu bireylerde yara iyileşmesini yanlışlıkla bozabilir. Aşırı demir yüklenmesi bağışıklık sistemini tehlikeye sokmakla kalmaz, aynı zamanda anjiogenezin sürdürülmesine yardımcı olan vasküler endoteliyal growth faktörün inhibe edicisinin sentezi ve salınmasına neden olabilir (Thangarajah vd., 2009).

Son olarak $\mathrm{KBH}$ olan hastalarda sıklıkla aşırı volüm yüklenmesi sonucu alt ekstremitelerinde oluşan ödem yara iyileşmesine karşı başka bir engel oluşturur (Scholnick, 2016).

Ayak Ülserasyonları Yönetiminde Hemşirenin Rolü ve Ayak Bakım Programları/Prediyaliz Eğitim Programları

Ayak komplikasyonları, uzun süreli diyabet ve SDBH olan hastalarda, SDBH olmayanlara göre daha yaygındır. Böbrek hastalığı olan hastalarda diyabetik ayak sendromu riski ve bu populasyonda onunla ilişkili morbidite ve mortalite artmıştır. Buna rağmen çoğu diyaliz merkezinde hemşireler tarafından bu durumun erken tespiti için tarama protokollerinin bulunmadığı, prediyaliz eğitim programları içerisinde bu konunun yer almadığı görülmektedir (Van den Bosch, Warren ve Rutherford, 2015).

Birçok çalışma, diyaliz merkezlerinde sürdürülen ayak bakım programları ile ilgili net faydalar göstermektedir (Marn Pernat vd., 2016; Lavery vd. 2010). Pernat ve ark.'nın diyabeti olan HD hastalarında hemşireler tarafından yapılan ayak kontrolleri ile alt ekstremite amputasyon oranları arasındaki ilişkiyi araştırmak amacıyla yaptıkları çalışmalarında, aylık ayak kontrollerinin, majör alt ekstremite amputasyonlarının azalması ile ilişkili olduğunu tespit etmişlerdir. Böylelikle diyaliz sırasında ayak kontrolleri uygulanmasının, amputasyon ve morbiditeyi azaltma ve yaşam kalitesini iyileştirme potansiyeline sahip ola 
bileceği ortaya konmuştur (Marn Pernat vd., 2016).

Ayak hastalıklarını önleme stratejileri, ayak ülserasyonu riskine rağmen, diyaliz hastalarının rutin tedavisine nadiren dahil edilir. Yapılan bir çalışmada, \%93'ünde diyabet hastalığı olan 150 diyaliz hastasının sadece \%1,3'ünün formal eğitim aldığı, \%7,3'ünün terapötik ayakkabı ya da tabanlığa sahip olduğu, \%30'unun koruyucu podiatrik bakım aldığı tespit edilmiştir (Lavery vd., 2010).

\section{Sonuç}

Diyaliz ünitelerinde ayak değerlendirme programları daha çok cilt ve tırnak patolojisi, periferik nöropati ve ülser oluşumu gibi yüksek riskli ayakları ortaya çıkaran uygulamaları kapsamaktadır. Wilson ve Lawrence'nin HD ünitesinde ayak değerlendirme programını uyguladıkları çalışmalarında, HD birimine aktarılan tüm hastalar için bir defalık tam risk değerlendirmesi ve bunu takiben yüksek riskli (diyabeti olan hastalar gibi) kabul edilenler için aylık ayak kontrollerini yapmışlardır. Sonucunda hem hasta hem de HD hemşiresi tarafından programın değerlendirmesi olumlu olmuş, hastaların yüksek riskli ayak yönetimi ve bakımında özdenetim üzerine daha büyük bir vurgu yapılmıştır. Aynı zamanda program, hastaların problemlerinin derhal belirlenmesi ve onların bölgelerindeki uygun hizmetlere zamanında yönlendirilmesi ile sonuçlanmıştır (Wilson ve Lawrence, 2013).

Diyabeti olan hastalarda, hastalığın mikrovasküler komplikasyonu olan ayak ülserasyonuna yönelik eğitim hizmetleri diyabet polikliniklerinde poliklinik hastalarına verilmektedir. Hatta diyabeti olan hastalarda gelişebilecek ayak sorunları ço- ğunlukla komplikasyonlar ortaya çıktıktan sonra ele alınmaktadır. Ülkemizde ayak ülserasyonları sadece diyabete atfedilmiş olup, ayak ülserasyonları açısından riskli olabilecek gruplar (SDBY olan hastalar gibi) göz ardı edilmektedir. Diyaliz hastaları genellikle diyaliz ortamının dışında bakımla temasını kaybederken, rutin diyaliz bakımının bir parçası olarak hemşireler tarafından değerlendirme, eğitim verme gibi koruyucu stratejiler ülserasyon ve amputasyon oranlarını azaltmak için anahtar olabilir.

Diyaliz ünitesinde önerilen bir ayak bakım programı modeli aşağıda gösterilmiştir (Şekil 1). Buna göre diyaliz ünitesi içerisinde yer alan hemşire tüm hastaları PAH, kallus, nasır gibi ayak deformiteleri, preülseratif veya ülseratif lezyonlar açısından değerlendirir. Periferik arter hastalığı saptanan hastalar kalp-damar cerrahisi uzmanı tarafından, ayak deformiteleri, preülseratif veya ülseratif lezyon saptanan hastalar podiatrist ya da orthotist (ortez uzmanı) tarafından, malnütrisyon ve elektrolit dengesizlikleri olan hastalar nutrisyonist tarafından değerlendirilir. Nefrolog, podiatrist, orthotist, vasküler cerrahi uzmanı, nutrisyonist ve hemşireden oluşan konsey hastalarda saptanan anormal bulgulardaki ilerlemeleri tartışmak ve hedefleri belirlemek için düzenli olarak toplanır.

\section{Finansal Destek:}

Bu çalışma sırasında, yapılan araştırma konusu ile ilgili doğrudan bağlantısı bulunan herhangi bir ilaç firmasından, tıbbi alet, gereç ve malzeme sağlayan ve/veya üreten bir firma veya herhangi bir ticari firmadan, çalışmanın değerlendirme sürecinde, çalışma ile ilgili verilecek kararı olumsuz etkileyebilecek maddi ve/veya manevi herhangi bir destek alınmamıştır.
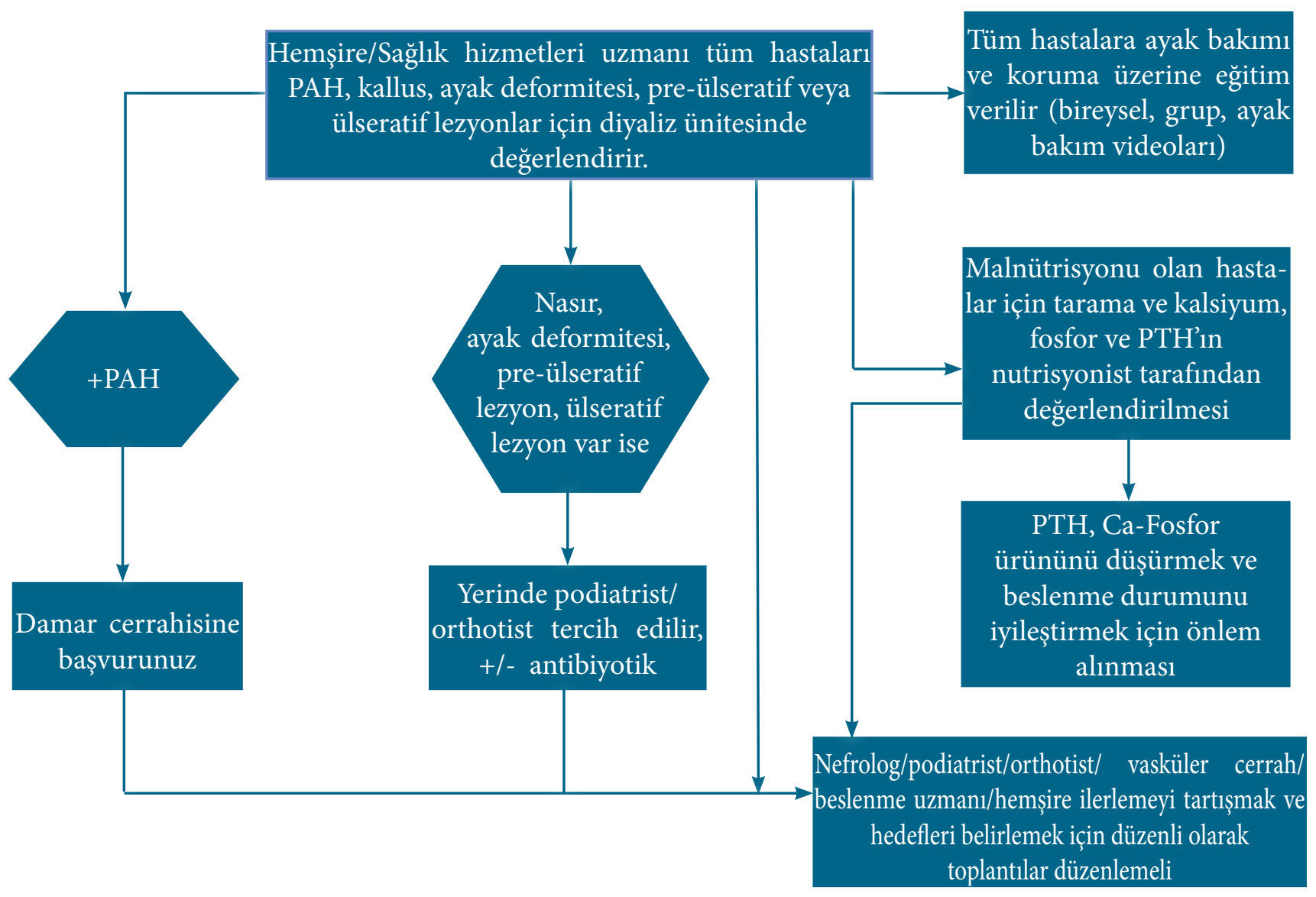

Şekil 1: Diyaliz ünitesinde hastalar için ayak bakım modeli (Lewis vd., 2012) 


\section{Çıkar Çatışması:}

Bu çalışma ile ilgili olarak yazarların ve/veya aile bireylerinin çıkar çatışması potansiyeli olabilecek bilimsel ve tıbbi komite üyeliği veya üyeleri ile ilişkisi danışmanlık, bilirkişilik, herhangi bir firmada çalışma durumu, hissedarlık ve benzer durumları yoktur.

\section{Yazar Katkıları:}

Bu çalışma tamamen yazarların kendi eseri olup, başka hiçbir yazar katkısı alınmamıştır.

\section{Kaynaklar}

1. Afsar, B. \& Akman, B. (2009). Depression and nonadherence are dosely related in dialysis patients. Kidney International, 76(6), 679

2. Al Thani, H., El-Menyar, A., Hussein, A., Sadek, A., Sharaf, A., Singh, R., ... Al Suwaidi, J. (2013). Prevalence, predictors and impact of peripheral arteria disease in hemodialysis patients: A cohort study with a 3-year follow-up. Angiology, 64(2), 98-104. https://doi.org/10.1177/0003319711436078

3. Al-Thani, H., El- Menyar, A., Koshy, V., Hussein, A., Sharaf, A., Asim, M. \& Sadek A. (2014). Implications of foot ulceration in hemodialysis patients: A 5-year observational study. Journal of Diabetes Research, Article ID 945075, 6 pages. http://dx.doi.org/10.1155/2014/945075

4. Allison, G. M. \& Flanagin, E. (2020). How ESKD complicates the management of diabetic foot ulcers: The vital role of the dialysis team in prevention, early detection, and support of multidisciplinary treatment to reduce lower extremity amputations. Seminars in Dialysis, 33(3s), 245-253. https://doi. org/10.1111/sdi.12875

5. Beyene, R. T., Derryberry, S. L. Jr. \& Barbul, A. (2020). The effect of comorbidities on wound healing. The Surgical clinics of North America, 100(4), 695-705. https://doi.org/10.1016/j.suc.2020.05.002

6. Brand, S. L., Musgrove, A., Jeffcoate, W. J. \& Lincoln, N. B. (2016). Evaluation of the effect of nurse education on patient-reported foot checks and foot care behaviour of people with diabetes receiving haemodialysis. Diabetic Medicine, 33(2), 204-7. https://doi.org/10.1111/dme.12831

7. Brekelmans, W., Borger van der Burg, B. L. S., Vroom, M. A., Kreuger, M. J., Schrander van der Meer, A. M. \&Hoencamp, R. (2019). Prevalence of foot ulcers in dialysis-dependent patients. Wound Repair Regeneration, 27(6), 687-692. https://doi.org/10.1111/wrr.12750

8. Cozzolino, M., Ciceri, P., Galassi, A., Mangano, M., Carugo, S., Capelli, I. \& Cianciolo, G. (2019). The key role of phosphate on vascular calcification. Toxin (Basel), 11(4), 213. https://doi.org/10.3390/toxins11040213

9. Demling, R. H. (2009). Nutrition, anabolism and the wound healing process: an overview. Eplasty, 9, e9.

10. De Vinuesa, S. G., Ortega, M., Martinez, P., Goicoechea, M., Campdera, F. G. \& Luño, J. (2005). Subclinical peripheral arterial disease in patients with chronic kidney disease; prevalence and related risk factors. Kidney International Supplement, 93, S44-47. https://doi.org/10.1111/j.1523-1755.2005.09310.x

11. El Sharaawy, A. E. B., Ezzat, H., Mohab, A. \& Elwasly, D. (2017). Association between renal function and diabetic foot ulcer in type 2 diabetic patients. International Journal of Advanced Research in Biological Sciences, 4(11), 7-15. http://dx.doi.org/10.22192/ijarbs.2017.04.11.002

12. Foster, S. (2017). High-risk foot and the effect of deteriorating renal funct on and dialysis in people with diabetes. Journal of Diabetes Nursing, 21(1), $10-15$.

13. Gilhotra, R. A., Rodrigues, B. T., Vangaveti, V. N., Kan, G., Porter, D., Sangla, K. S. \& Malabu, U. H. (2016). Non-traumatic lower limb amputation in patients with end-stage renal failure on dialysis: an Australian perspective. Renal Failure 38(7), 1036-1043. https://doi.org/10.1080/0886022X.2016.1193872

14. Han, G. \& Ceilley, R. (2017). Chronic wound healing: a review of current management and treatments. Advances in Therapy, 34(3), 599-610.

15. Ikizler, T. A., Cano, N. J., Franch, H., Fouque, D., Himmelfarb, J., Kalantar-Zadeh, K.,... Wanner, C. (2013). Prevention and treatment of protein energy wasting in chronic kidney disease patients: a consensus statement by the international society of renal nutrition and metabolism. Kidney International, 84(6) 1096-1107. https://doi.org/10.1038/ki.2013.147

16. Kalantar-Zadeh, K. \& Kopple, J. D. (2003). Trace elements and vitamins in maintenance dialysis patients. Advances in Renal Replacement Therapy, 10(3), 170-182. https://doi.org/10.1053/j.arrt.2003.09.002

17. Kaminski, M. R., Raspovic, A., McMahon, L. P., Lambert, K. A., Erbas, B., Mount, P. F., Kerr, P. G. \& Landorf, K. B. (2017). Factors associated with foot ulceration and amputation in adults on dialysis: a cross-sectional observational study. BMC Nephrology, 18, 293.

18. Kaminski, M. R., Raspovic, A., McMahon, L. P., Strippoli, G. F. M., Palmer, S. C., Ruospo, M., Dallimore, S. \& Landorf, K. B. (2015). Risk factors for foot ulceration and lower extremity amputation in adults with end-stage renal disease on di alysis: A systematic review and meta-analysis. Nephrology, dialysis, transplantation, 30(10), 1747-1766. https://doi.org/10.1093/ndt/gfv114

19. Kato, S., Chmielewski, M., Honda, H., Pecoits-Filho, R., Matsuo, S., ... Lindholm, B. (2008). Aspects of immune dysfunction in end-stage renal disease. Clinical Journal of the American Society of Nephrology, 3(5), 1526-1533. https://doi. org/10.2215/CJN.00950208

20. Kay, D. B., Ray, S., Haller, N. A. \& Hewit, M. (2011). Perfusion pressures and distal oxygenation in individuals with diabetes undergoing chronic hemodialysis. Foot Ankle International, 32(7), 700-703. https://doi.org/10.3113/ FAl.2011.0700

21. Khanh, V. C., Ohneda, K., Kato, T., Yamashita, T., Sato, F., Tachi, K. \& Ohneda, $O$. Uremic toxins affect the imbalance of redox state and overexpression of prolyl hydroxylase 2 in human adipose tissue-derived mesenchymal stem cells involved in wound healing. (2017). Stem Cells and Development, 26(13), 948-963. https://doi.org/10.1089/scd.2016.0326

22. Krishnan, A. V., Pussell, B. A. \& Kiernan, M. C. (2009). Neuromuscular disease in the dialysis patient: $A$ update for the nephrologist. Seminars in Dialysis, 22(3), 267-278. https://doi.org/10.1111/j.1525-139X.2008.00555.x

23. Lavery, L. A., Hunt, N. A., Lafontaine, J., Baxter, C. L., Ndip, A. \& Boulton, A J. (2010). Diabetic foot prevention: a neglected opportunity in high-risk patients. Diabetes Care, 33(7), 1460-1462.

24. Lavery, L. A., Lavery, D. C., Hunt, N. A., La Fontaine, J., Ndip, A. \& Boulton, A. J. (2015). Amputations and foot-related hospitalisations disproportionately affect dialysis patients. International Wound Journal, 12(5), 523-526. https:// doi.org/10.1111/iwj.12146

25. Lewis, S., Raj, D. \& Guzman, N. J. (2012). Renal failure: Implications of chronic kidney disease in the management of the diabetic foot. Seminars in Vascula Surgery, 25(2), 82-88. https://doi.org/10.1053/j.semvascsurg.2012.04.007

26. Lin, C. S., Chen, S. J., Sung, C. C., Lin, C. L., Lin, S. H., Cheng, S. M., ... Kao, C. H. (2015). Hemodialysis is associated with increased peripheral artery occlusive disease risk among patients with end-stage renal disease: A nationwide population-based cohort study. Medicine (Baltimore), 94(28), e1164.

27. Lincoln, N. B., Radford, K. A., Game, F. L. \& Jeffcoate, W. J. (2008). Education for secondary prevention of foot ulcers in people with diabetes: a randomised controlled trial. Diabetologia, 51(11), 1954-1961.

28. Locking-Cusolito, H., Harwood, L., Wilson, B., Burgess, K., Elliot, M., Gallo, K., .. Tigert, J. (2005). Prevalence of risk factors predisposing to foot problems in patients on hemodialysis. Nephrology Nursing Journal, 32(4), 373-384.

29. Margolis, D. J., Hofstad, O. \& Feldman, H. I. (2008). Association between renal failure and foot ulcer or lower-extremity amputation in patients with diabetes. Diabetes Care, 31(7), 1331-1336. https://doi.org/10.2337/dc07-2244

30. Marn Pernat, A., Peršič, V., Usvyat, L., Saunders, L., Rogus, J., Maddux, F. W.,... Kotanko, P. (2016). Implementation of routine foot check in patients with diabetes on hemodialysis: associations with outcomes. BMJ Open Diabetes Research Care, 4(1), e000158. doi: 10.1136/bmjdrc-2015-000158

31. Maroz, N. \& Simman, R. (2014). Wound healing in patients with impaired kidney function. The journal of the American College of Clinical Wound Specialists, 5(1), 2-7.

32. Meuwese, C. L., Carrero, J. J. \& Stenvinkel, P. (2011). Recent insights in inflammation-associated wasting in patients with chronic kidney disease. Contributions to Nephrology, 171, 120-126. https://doi.org/10.1159/000327228

33. Ndip, A., Lavery, L. A. \& Boulton, A. J. M. (2010). Diabetic foot disease in people with advanced nephropathy and those on renal dialysis. Current Diabetes Reports, 10(4), 283-290.

34. Ndip, A., Rutter, M. K., Vileikyte, L., Vardhan, A., Asari, A., Jameel, M., ... Boulton, A. J. M. (2010). Dialysis treatment is an independent risk factor for foot ulceration in patients with diabetes and stage 4 or 5 chronic kidney disease. Diabetes Care, 33(8), 1811-1816. https://doi.org/10.2337/dc10-0255

35. Nigwekar, S. U., Wolf, M., Sterns, R. H. \& Hix, J. K. (2008). Calciphylaxis from nonuremic causes: a systematic review. Clinical Journal of the American Society of Nephrology, 3(4), 1139-1143. https://doi.org/10.2215/CJN.00530108

36. Pappanas, N., Liakopoulos, V., Maltezos, E. \& Stefanidis, I. (2007). The diabetic foot in end stage renal disease. Renal failure, 29(5), 519-528. https://doi. org/10.1080/08860220701391662

37. Reardon, R., Simring, D., Kim, B., Mortensen, J., Williams, D. \& Leslie, A. (2020). The diabetic foot ulcer. Australian Journal of General Practice, 49(5), 250-255. doi: 10.31128/AJGP-11-19-5161

38. Reslerova, M. \& Moe, S. M. (2003). Vascular calcification in dialysis patients: pathogenesis and consequences. American Journal of Kidney Disease, 41(3 Suppl 1), S96-99. https://doi.org/10.1053/ajkd.2003.50094

39. Rodriguez, P. G., Felix, F. N., Woodley, D. T. \& Shim, E. K. (2008). The role of oxygen in wound healing: a review of the literature. Dermatologic Surgery, 34(9), 1159-69. https://doi.org/10.1111/j.1524-4725.2008.34254 x

40. Sabatino, A., Regolisti, G., Karupaiah, T., Sahathevan, S., Sadu Singh, B. K., Khor B. H., ... Fiaccadori, E. (2017). Protein-energy wasting and nutritional supplementation in patients with end-stage renal disease on hemodialysis. Clinical Nutrition, 36(3), 663-671. https://doi.org/10.1016/j.clnu.2016.06.007

41. Saluja, S., Anderson, S. G., Hambleton, I., Shoo, H., Livingston, M., Jude, E. B. Lunt, M., Dunn, G., Heald, A. H. (2020). Foot ulceration and its association with mortality in diabetes mellitus: a meta-analysis. Diabetic Medicine, 37(2), 211 218. https://doi.org/10.1111/dme.14151

42. Scholnick, K. (2016). The effects of renal disease on wound healing. Podiatry Management, 35(2), 133-140.

43. Shroff, R. C., McNair, R., Figg, N., Skepper, J. N., Schurgers, L., Gupta, A. ... Shanahan, C. M. (2008). Dialysis accelerates medial vascular calcification in part by triggering smooth muscle cell apoptosis. Circulation, 118(17), 1748-1757. https://doi.org/10.1161/CIRCULATIONAHA.108.783738

44. Thangarajah, H., Yao, D., Chang, E. I., Shi, Y., Jazayeri, L., Vial, I. N., ... Gurtner, G. C. (2009). The molecular basis for impaired hypoxia-induced VEGF expression in diabetic tissues. Proceedings of the National Academy of Sciences of the United States of America, 106(32), 13505-13510.

45. Wilson, B. \& Lawrence, J. (2013). Implementation of a foot assessment prog ram in a regional satellite hemodialysis setting. CANNT Journal, 23(2), 41-7.

46. Valabhii, J. (2011). Reducing amputations at a multidisciplinary diabetic foot 
clinic in London. The Diabetic Foot Journal, 14(2), 63-70.

47. Valabhji, J. (2012). Foot problems in patients with diabetes and chronic kidney disease. Journal of Renal Care, 38(Suppl 1), 99-108. https://doi.org/10.1111/j.1755-6686.2012.00284.x

48. Valabhji, J., Gibbs, R. G., Bloomfield, L., Lyons, S., Samarasinghe, D., Rosenfeld P., ... Bicknell, C. D. (2010). Matching the numerator with an appropriate denominator to demonstrate low amputation incidence associated with a London hospital multidisciplinary diabetic foot clinic. Diabetic Medicine, 27(11) 1304-1307. https://doi.org/10.1111/j.1464-5491.2010.03104.x

49. Van den Bosch, J., Warren, D. S. \& Rutherford, P. A. (2015). Review of predialysis education programs: a need for standardization. Patient Preference and Adherence, 9, 1279-1291. https://doi.org/10.2147/PPA.S81284

50. Vanholder, R., Pletinck, A., Schepers, E. \& Glorieux, G. (2018). Biochemical and clinical impact of organic uremic retention solutes: A comprehensive update. Toxins, 10(1), 33. https://doi.org/10.3390/toxins10010033 